\title{
Women's Faces against Patriarchal Domination A Further Study of the Film Marlina the Murderer in Four Acts using Algirdar Greimas' Narrative Semiotics Theory
}

\author{
Zulfa Aulia \\ London School of Public Relations Jakarta
}

\begin{abstract}
This study entitled Women's Faces Against Patriarchal Domination, a further study of the film Marlina The Murderer in Four Acts using Algirdar Greimas' narrative semiotics theory. The research will find out the actant model and functional model to see the plots, characters and hidden aim inside the text. The research also sees Richard Krevolin's Scene-o-gram model to sharpen the plot and characters in the film. The results of the study show that the six actants in the Greimas model are mentioned as subject, object, sender and recipient showed the meaning of the struggle against patriarchal domination that occurs throughout the story with violence and emotion as the main traitors and female characters who are the helpers of the main characters in achieving their desires. Meanwhile, a conflict-filled storyline can be read in a functional scheme that tells the beginning, the transformation that contains conflict until the final situation as the end of the story in the film. From the semiotic square, it can be found that the inner structure which is the main theme in this film is about masculine versus feminine as a simple movement of feminism to fight the gap among gender and ethical versus indelicate as a reflection of eastern Indonesian culture.
\end{abstract}

Keywords:- narrative semiotics, Greimas, scene-o-gram, patriarchy, feminism.

\section{INTRODUCTION}

Ideas, opinion, messages or events about anything can now be made using film which is a form of visual technology and also with the idea of depicting patriarchal domination as an issue of feminism that develops in society. The film of Marlina the Murderer in Four Acts (hereinafter referred to as MTMIFA) is one of the films which raises the issue of feminism which seems to be the theme of a film that is always fresh to be enjoyed on the big screen. If Wright in Sobur says that two film themes that often cause anxiety in society are violence and sex, then the director Mouli Surya brings up the two themes into one whole story to start this film.

Violence against women still occurs in developing countries such as Indonesia. Violence against women that occurs in Indonesia occurs because of the "vulnerable position" of women from strong patriarchal domination as well as a culture of discrimination and a culture of unequal relationships between men and women, husband and wife and other relationships.

From the data presented by the national women's commission, it is also known that the highest types of women's violence in the community realm are rape and sexual immorality. Of course, this act of violence is not without consequences for the victims, some of the consequences that arise are trauma, depression, attempted suicide to death during the incident. Not many victims of raped are able to fight for their rights or protect themselves.

Films can come from real-life events around humans to fictional things that come from someone's shadow or imagination. Films have many advantages, namely being able to display objects that cannot be seen with the naked eye, films are able to show very large objects, very small objects, slow down the movement of objects that are too fast or too slow and accelerate movements that are too slow. Films are able to give the impression of being more exaggerated than a certain event (Miyarso, 2009, p. 1).

Today's films have undergone many changes in function. Film, which was originally only used as a medium of entertainment and art, is now often used by creative people as social criticism or a medium to convey messages on phenomena that are developing in society.

Film in the narrow sense is the presentation of images through the big screen, but in a broader sense it can also include those broadcast on TV. Film is one of the mass media in the form of audio visual and its very complex nature. The existence of films today has a different meaning compared to other mass media. Films can record the reality that develops in society which is shown on the big screen. Films are also known to have the ability to reach many social segments. Experts argue that films have the potential to influence audiences (Sobur, 2006, p. 127)

The revival of Indonesian films was felt in the 2000s. Various genres of films began to emerge from horror, drama to action.

Not only are they increasingly in demand in the eyes of local audiences, many Indonesian films have also succeeded in making Indonesia proud in the international 
film festival. MTMIFA is the third film by Mouly Surya to be awarded the Cannes Film Festival award. The film, which was released in 2017, also won 5 awards and was nominated for 12 other international awards.

Some of the awards included the best participant at the 2017 Tokyo Filmex in Tokyo, best actress for Marsha Timothy from the Sitges International Fantastic Film Festival, Spain, and the Asian Nest Wave best film award from The QCinema Film Festival, Philippines. In 2018 the Marlina Film even won 10 awards from the 13 categories that nominated this film at the Indonesian Film Festival, which finally made this film the winner of the Citra Cup with the most award winners throughout this film award event that has been going on since 1955 .

Even after being shown on the cinema screen in 2017, this film returned to the cinema after winning 10 Citra Cup nominations in January 2019. In accordance with the title of the film, the film director is divided into 4 story segments there are robbery, travel, confession and birth.

Marlina as the main character of this film represent as a widow who lives alone in Sumba, East Nusa Tenggara, Indonesia, because her husband died. One afternoon a person named Markus arrived who claimed to be bringing 6 other friends and would rob and rape Marlina. Pretending as a guest, Markus asked him to cook a dinner with chicken soup menu before his friends came.

Seeking a way to finish off the robbers, Marlina took out the poisonous fruit named, that she had kept in her dresser drawer and mixed it into the chicken soup she made. In the evening when 4 robbers came and ate the chicken soup, they died instantly. The other 2 robbers had left before the evening meal with all his livestock to sell.

However, the attempt to poison Markus, the head of the gang of robbers, was unsuccessful. While handing the chicken soup to Markus who was resting in Marlina's bedroom, Markus grabbed Marlina and made him drop the chicken soup. Marlina was eventually raped by Markus, instead of screaming Marlina instead used Markus' machete which she put on the mattress to cut off its master's head.

The scene cut is used as a prologue narrative for the audience to understand the existing issue of feminism, where the dominance of patriarchy which is still ingrained in eastern culture still makes women a minority group. The phenomenon of feminism that is usually carried out by middle class women or comes from western culture, by Mouly Surya is attached to the figure of Marlina who lives in an eastern country with conditions of poverty and far from the word modernity.

Feminism itself has developed since the 16-18 century in Europe, with the main issue demanding gender equality. We have known the feminism-movement in Indonesia itself from the historical history of Indonesia which had so many female fighters such as RA Kartini, Cut Nyak Dien and Dewi Sartika. The issues that were fought for themselves have changed from time to time.
Feminism was initially heard using the issue of rights and equality as the basis of its struggle. But in the late 1960s, the feminism-movement began to use the terms "oppression" and "freedom" which in turn called itself the "women's liberation movement" (Kania, 2012).

MTMIFA films like other women-themed films also use the intermediary of the patriarchal phenomenon to lift the existing power of the main character. It's just that when acts of feminism are carried out by women in remote areas such as Sumba, this feminist behavior is only done for themselves.

The only way messages can be sent from one person to another is by using a code (Nur, 2013, p.73). And film is one of the media that is often used as a medium for delivering messages full of critical codes and social phenomena in packaging that is easier for the public to accept and enjoy. Mouly Surya conveyed forms of violence against women into moving pictures in the MTMIFA film. Many codes in this film can be dissected and interpreted by semiotic studies.

Semiotic studies are often used to analyze media texts with the assumption that the media itself is communicated through a set of signs. The media text which is composed of a set of signs never carries a single meaning (Sobur, 2006, p. 95). Semiotic analysis is paradigmatic, which means an attempt to find the hidden things of a text (Wibowo, 2009, p. 7). That is why sometimes semiotic analised using narrative analysis is also often used to reveal the meanings that exist not only in written works such as news and novels but also audio visual works such as films and advertisements.

The MTMIFA film is interesting to study in a narrative way, because this film has divided its story plot by making a large division of the story the title of the film. One of the figures who developed narrative analysis was a linguist from Lithuania, Algirdas Julius Greimas, whose understanding is better known as narrative semiotics.

Film is one of the works of fiction which has 3 conditions at once so that it can be categorized as a narrative, namely having a series of events, is a sequential series and selecting one event to be displayed to match the meaning the narrator wants to convey (Eriyanto, 2013, p. 2). Greimas perfected Vladimir Propp's understanding of the character's understanding of the narrative. Besides examining the function of each character, Greimas considers that the relationships between characters are equally important to understand. These characters are categorized into six roles or better known as six actansial models. Then to understand the nature of the existing reality, the researcher will use a semiotic square which is the development of the Levi-Strauss binary opposition model. 


\section{LITERATURE REVIEW}

\section{A. Feminism}

As if to show that the feminism- movement can not only be done directly, but also feminism can be shown through literary works such as films. Instead of depicting the form of patriarchy in Indonesia that is so thick, the film Marlina the Murderer in Four Acts (hereinafter referred to as MTMIFA) also presents forms of resistance to patriarchy typical of the radical-libertarian feminist movement.

Researchers in writing this thesis will use the theory of feminism which will be analyzed qualitatively. Because the object to be dissected is a film, the researcher will use the semiotic research method, which is classified as part of the Discourse Analysis research method, which adopts a constructivist paradigm.

The essence of feminist research is basically paying attention to the cultural construction of two living things, namely men and women. Feminism theory seeks to analyze the various conditions that shape women's lives and to investigate various cultural understandings of what it means to be a woman. Initially, the theory of feminism was directed by the political objectives of the women's movement - namely the need to understand women's subordination and the execution or marginalization of women in various cultural and socialist areas (Basarah, 2016, p.107)

\section{B. Patriarchy}

The phenomenon of gender inequality (read: bias) is still occurring, more due to the ongoing domination of patriarchy which is embraced by most nations in the world. The view that men are stronger, stronger, more entitled to occupy important roles has constructed a cultural order that favors men more than women. This cultural construct continues from century to century and from generation to generation, so that our society finds it difficult to distinguish between what is called "kodrat" and "cultural construct" as a product of human creation (Nanang, 2015).

To describe the form of patriarchal action in private life, feminists emphasize the phrase "the personal is political". Second wave feminists (especially radicallibertarian) use this expression to highlight oppression against women in the private sphere, especially in the gender characterization system based on sex, which always associates men with masculinity and women with femininity (Sofranita, 2015).

According to Millet in Tong (1998), patriarchal ideology exaggerates biological differences between men and women, and always ensures that men are always in a masculine and dominant position, while women are always feminine or subordinate. Because this ideology is so strong, men don't even need the consent of the women they dominate. Even according to radical feminists, men as the worst individual are not the main oppressors of women, because the main enemy of women is the patriarchal system, which is a product that has been produced for centuries that produces profits, priorities and prerogatives that make it easier for men (p. 10).

\section{Androgyny}

Androgyny is an issue raised by radical-liberal feminists to solve gender problems. This term comes from two words in Greek, namely $\alpha v \eta ́ \rho$ (anér, which means man) and yvví (guné, which means woman). However, not a few people mistakenly interpret androgynous as a shift in sexual orientation, women who are men or men who look like women. Whereas being androgynous is an attempt to combine masculine and feminine dimensions to become equally dominant regardless of the gender of the androgynous person.

Block classified several types of androgyny that may occur in an individual: (1) individuals with both high masculine and femininity known as androgyny; (2) high femininity with less masculinity, where if this happens to women it is called a gender type and if it occurs in men it is called a cross gender type; (3) femininity with high masculinity, if it occurs in women it is called the cross gender type and if it occurs in men it is called the gender type; (4) masculine and less femininity, if it occurs in men or women, both are referred to as undifferentiated (Andi Tenri Pada Agustang, 2015).

Androgyny is a notion that does not support the assumption that masculinity is good for men and femininity is good for women. Androgyny exists because the ideal human assumption is one that combines masculine arrogance and feminine obedience so that the combination of forces that is formed will complement each other so that androgin can live better in the community (Tong, 1998, p.77).

Androgyny can be said as a form of positive gender flexibility, openness to the implementation of cross roles between genders so as to minimize oppression from one another.

\section{Narrative and Narrative Analysis}

Narrative is a representation or series of stories from events (Eriyanto, 2013). Two aspects that are quite important to know in understanding narrative are the story and the story line (plot). Both are often used in describing a narrative, which one is displayed or not shown. There are four basic principles in making narrative essays: plot, character, setting, point of view (Yunus, 2008, p. 39).

According to Bordwell \& Thompson in Arsi (Arsi, 2019), a series of events or events that occur in the narrative are arranged through a causal relationship in certain space and time. For Fisher, narrative includes any verbal or nonverbal description of the sequence of events that the listeners assign meaning. Narrative is also not a special genre like poetry, but a form of social influence (Shah, 2017). The emergence of the term "narrative" shows that as in analyzing stories in general, the focus of the study is on the actors, the beginning, middle and end of the story, relationships and functions, and motives (Maryaeni, 2005). 
Several literary scholars came up with ideas for narrative structure in the text. What some experts have in common is that the narrative structure has a structure from beginning to end. Tzetan Todorov in Eriyanto (Eriyanto, 2013, p.46) describes the structure of the narrative starting from balance (equilibrium) - disturbance (chaos) equilibrium (balance). Nick Lacey then modifies this structure by adding a few steps so that it becomes a balance - disturbance of balance - awareness of disturbance attempts to correct the disturbance - recovery to balance ( $p$. 47).

Narrative analysis is interesting to use by researchers because it has several advantages: first, it helps in understanding the production of knowledge, meaning and value, as well as its dissemination in society. Second, narrative analysis can also be used to understand social and political storytelling in society from a certain point of view and to understand the forces and values that are more dominant in society. Third, narrative analysis can also be used to uncover hidden and latent things in a media text. Fourth, narrative analysis is also used to reflect continuity and change in communication (Eriyanto, 2013).

All depictions of phenomena in society will usually be described according to how the meaning wants to be understood by those who read. In a fictional story, the story maker will display the subjectivity side through the characters to describe their ideas or opinions about the reality to be conveyed. For example the storyteller wants to convey that violence is a bad thing, and the perpetrator can be held accountable for his actions, the story teller must create the character of the perpetrator of violence, the victim, and other characters who help the perpetrators of violence and victims from the beginning to the end so that a narrative can be formed that is intact.

\section{E. Plot}

Plot usually appears explicitly in a text, or if in a film it is usually displayed in a script or script. Meanwhile, the story is a chronology of an event that can appear explicitly or implicitly in the text. Another way to distinguish between story and plot is how an event is integrated (Eriyanto, 2013, p. 16).

If the story is a complete event from beginning to end and is always sequential, while the plot is an event that is explicitly written in the text and the delivery can be reversed depending on the story teller. Linear plotting usually has story telling sequentially over time without significant time interruptions, while plots that have a nonlinear pattern are usually used to manipulate the time sequence of events, resulting in biased and unclear causality, and often confusion.

The plot demands in a work of fiction are more than just a story. The plot demands clarity between the events narrated, not just a temporal sequence. This is what cannot be found in stories because stories tend to be simpler and the order of events must be chronological. If we want to know the greatness of a story, then it can be filled with a synopsis or summary of the story. This is not in accordance with the framework of plot analysis, where the plot usually provides a detailed and detailed story besides that it does not only have the main conflict but also the supporting conflicts that become the development of the plot. Three things are important elements in the development of the plot, namely events, conflicts and climax (Nurgiyantoro, 2002, pp. 96-97).

Broadly speaking, the plot is a way for a character to realize his vision or to get what he wants. This includes the part where a character is assisted and hampered by events or other characters.

\section{F. Characterization or Character}

Stanton in Nurgiyantoro (2002) explains that the use of the term character in various literatures refers to two different things, namely the character of the story that is displayed and the character's attitudes, interests, desires, emotions, and moral principles. However, a character often does have the same label with his character as Datuk Maringgih with his crimes, Bawang Putih with humility, and so on.

Characters are needed by story creators to represent the contents of the message, ranging from hero characters (good people), villains (antagonists) to supporting characters of heroes and villains (Eriyanto, 2013, p.65). In his narrative function, Vladimir Propp divides 31 functions into 7 characters, namely villain, donor, helper, princess and father, dispatcher, hero and the last is a false hero. The seven characters are then simplified by Greimas into two main character functions, namely heroism versus evil ( $p$. 74).

Another method that can help determine the structure of a film is Richard Krevolin's scene-o-gram model. Krevolin created a model whose main reference leads to the beginning of the story, the midpoint and the end point (Ikhsan, 2016). By making a scene-o-gram chart and answering seven big questions that are part of adaptation theory, it will be possible to find out how the story framework was built by the director (Adji, 2016). The top seven methods helps to analyze denotative, connotative and myth / ideological meanings.

\section{G. Algirdar Greimas Narrative Semiotics}

Semiotics is the study of signs. Little John in Sobur (Sobur, 2006, p. 15) says signs are the basis of all communication. Besides learning about the sign production process which is often known to be the basis of communication, namely senders, receivers, messages, channels or media; semotics also learns about its understanding in a particular context.

The field of semiotics can be carried out in various fields, from natural communication processes to more complex cultural systems. Eco in Sobur (Sobur, 2006, p.109) states that there are at least 19 fields that can be considered as materials for communication studies and two of them are plot structure and text theory, which in this study are quite relevant to be used in research narrative semiotics. 
Film is one of the sources of narrative semiotic research because it has a plot and plot. In addition, in the film there are also characters, as part of the narrative (story) which has their own characteristics and functions that make the story intact. Vladimir Propp is the first character to compose the characters in the narrative. Propp translates character functions in the narrative into 31 conceptualized functions of the character's actions in the narrative and the consequences of those actions in the narrative (Eriyanto, 2013, p.71)

Algirdar Greimas improved this character function into a simpler form and relates to one character to another. A narrative by Greimas is defined as the six roles which Greimas referred to as an actant and functions to direct the storyline. Each character can occupy several functions and roles in one acting model. The characters in the first model become objects can change into subjects in the next model, as well as other models. Each character can play a dual role depending on who is the object of each act (p. 98).

\section{H. Semiotic Rectangle Model}

The Greimas actor model is known as the outer structure of the narrative or in this study is the MTMIFA film. Then to reveal the inner structure that shows the reality that exists in MTMIFA, Greimas' semiotic square is used. Levi Strauss explores the structure in a narrative by using a binary opposition structure, by taking into account the human nature of seeing things from two opposing sides which is also associated with the function of a narrative in society. Meanwhile Greimas felt there was a lack of binary opposition models to divide reality. Greimas finds that many different circumstances are not always oppositional (Eriyanto, 2013, p. 197)

The Greimas Semiotic Square Model is used to reveal social phenomena that are not only in diametrically contradicting two conditions, but there are conditions in between. As an analytical tool, semiotic square should be able to display meaning coherently considering that all terms in a quadrilateral relation are able to show how homogeneous the world is (Hébert, 2011, p.44).

\section{RESEARCH METHODOLOGY}

\section{A. Research paradigm}

The author examined the narrative elements in the film Marlina the Murderer in Four Acts, in the form of plot, characters and conflicts that connect the plots in the form of dialogues in the film scene. The author also borrowed Richard Krevolin's scene-o-gram table to strengthen the character and plot of the film.

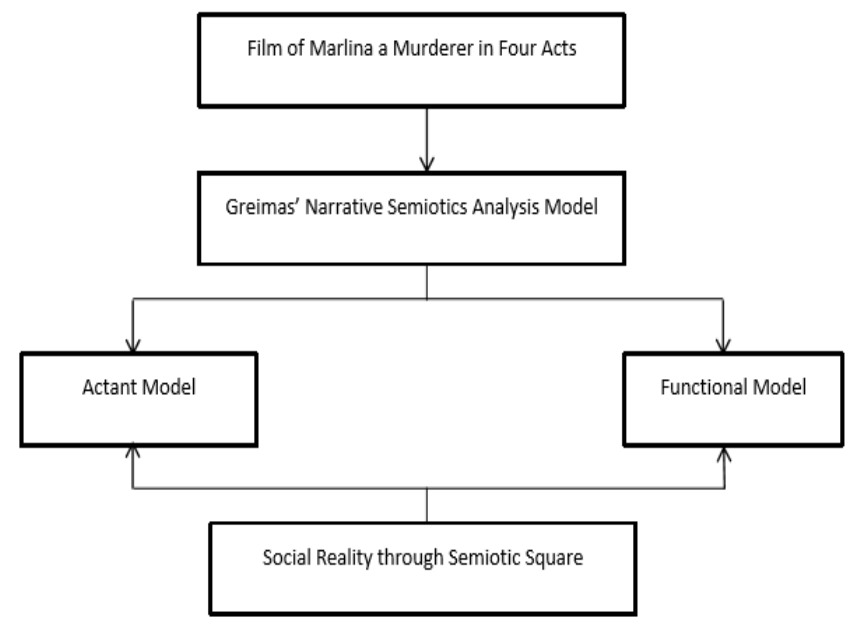

Fig 1:- Research Conceptual Framework

Harmon in Moleong (2004, p. 49) states that paradigm is a fundamental way to perceive, think, assess, and do that is related to something specifically about reality. In communication research, there are three major paradigms that are often used in a study, namely the classical paradigm (positivistic and post-positivistic), the critical paradigm and the interpretive or constructivist paradigm (Muslim, 2015).

Fisher defines narrative as "symbolic actions - words and / or actions - that have sequence and meaning for those who live, create or interpret them. Paradigm is a word used to refer to a conceptual framework. Paradigm is a universal model that invites people to see an event through a general interpretive lens. So that Fisher classified narrative into an interpretive paradigm, namely a paradigm for interpreting all forms of communication and rhetorical understanding (Griffin, 2011, p. 310).

The constructivist paradigm emphasizes empathy, and dialectical interaction between researchers and respondents to construct the reality under study through qualitative methods such as participant observations, and has research quality criteria, namely authenticity and reflectivity to the extent that findings are an authentic reflection of the reality that social actors live ( Hidayat, 2002).

\section{B. Research Method}

The researcher used narrative semiotic research method using Algirdas Greimas' model to reveal the form of resistance to patriarchal domination contained in the MTMIFA film.

Greimas' narrative semiotics is involved with the concept of structuralism, where the interpreter cannot be separated from the narrative structure being studied. Greimas combines narratology and semiotics which study sign systems that analyze social and cultural phenomena to make text studies more systematic and scientific (Istiqomah, 2017). 
Research with Greimas semiotics analyzed the signs in the film text by looking at the relationship or interaction between characters when conflicts occur so that the values in the story can be seen.

\section{Unit of Analysis}

Unit of analysis is the message that will be examined, through analysis of the message content in the form of images, titles, sentences, paragraphs, scenes in the film content or the entire message (Ghozali, 2005). Whereas in this study, the analysis unit will be visualization of images, audio (dialogue and music), wardrobe, gesture / acting, settings, type of shot, angle, and text in the MTMIFA film related to research topics regarding resistance to culture. patriarchy. This research will take several scenes to be analyzed including:

$>$ Scene 2 (00:02:45 - 00:09:45) Mark "visits" to Marlina's house

$>$ Scene 4a (00:10:35 - 00:13:24) Marlina annoyed with the robber's bed story

$>$ Scene 5a (00:18:11 - 00:20:40) 4 The robber died after eating chicken soup

$>$ Scene 5b (00:20:41 - 00:24:37) Mark was beheaded while raping Marlina

$>$ Scene 6b (00:31:09 - 00:33:24) Marlina is prohibited from taking transportation by the driver

$>$ Scene 8a (00:40:53 - 00:43:46) Novi and Marlina's toilet chat

Scene 9 (00:48:29 - 00:53:04) Marlina meets Topan

$>$ Scene $10(00: 53: 05-00: 56: 54)$ Marlina's report to the Police is futile

$>$ Scene 12 (01:00:57 - 01:05:30) Franz stroking his Katopo

$>$ Scene 13 (01:05:31 - 01:09:43) Novi fighting with Umbu

$>$ Scene 15 (01:11:48 - 01:17:18) Franz is crying

$>$ Scene $18(01: 22: 58-01: 27: 57)$ Franz is beheaded by Novi

\section{RESEARCH ANALYSIS}

Marlina the Murderer in Four Chapters (hereinafter referred to as MTMIFA) first aired in Indonesia on November 16, 2017. This film was directed by Mouly Surya who was previously known through the film What They Don't Talk About When They Talk About Love (2013) and Fiksi. (2008).

Since its premiere at Directors Fortnight in May 2017, MTMIFA films have been distributed in more than 40 countries including the United States, Canada, United Kingdom, Singapore and Italy. In 2019, the new MTMIFA film was also taken by Pandora to be shown in Japan (Brzeski, 2018).

Marlina is the main character in MTMIFA who lives alone in the area of Sumba, East Nusa Tenggara, Indonesia, because her husband died. The plot in this film has been divided into 4 part by the director. The storyline and the first conflict begin in the first act entitled The Robbery. Marlina (Marsha Timothy) is a widow who lives alone in an area in Sumba. Her husband (Tumpal Tampubolon) had just died and had not been buried because there was no money for the funeral procession. The body of Marlina's husband is still in the living room of her house, placed in a curled position like a newborn and wrapped in a typical Sumba cloth. From her late husband, Marlina was once pregnant with a boy but at 7 months of pregnancy, his son died and was buried in front of his house. Her son named Topan, as seen on his tombstone. However, to carry out the funeral procession for her son, Marlina's husband borrowed money from a bandit named Markus (Egy Fredly). And not yet finished paying off his son's burial debt, poor husband had passed away.

One day Markus came to Marlina's house. Marlina, who did not speak much, let Markus enter her house. While drinking the coffee served by Marlina, Markus said that 6 of his friends would come to take all of Marlina's livestock, and would rape her if they had time left. Markus came because her husband was unable to pay the debt left over from the burial of his late son.

When evening, 6 others came. They asked Marlina to cook a chicken soup dinner. Marlina finally poisoned Markus' and the gang by mixing poisonous sagas that Marlina kept in the dresser drawer of her room. The chicken soup he made and immediately killed 4 people who ate the soup made by Marlina, while the other 2 robbers, Franz (Yoga Pratama) and Niko (Haydar Salishz), had left before dinner bringing all of his livestock to sell.

The next scene in the second act, entitled The Journey. Marlina was waiting for a truck while carrying Markus' severed head to the police station. Here Marlina met with another Sumba woman, named Novi (Dea Panendra), who is waiting for the birth of the child she has been carrying for almost ten months. Novi is a friend of Marlina, who is described as cheerful, outspoken full of enthusiasm and courage. Even seeing Marlina carrying a head, she did not show excessive fear, Novi could still have a conversation as usual.

In the middle of the road, a truck driven by Marlina ran into a truck driven by Franz and one of his friends who were heading to his house. When they passed, Marlina hide under the chair so that she could not be seen. When Franz arrived at Marlina's house, he found 5 of his friends dead and made Franz and his friends run out of the house because of nausea. Franz and his friends then rushed to use their motorcycle to find Marlina.

In the third round, The Confession, described that Marlina was arriving in front of the police station. Marlina was suddenly called by a girl who was a food shop keeper to stop by her shop. The girl who turned out to be named Topan, similar to the name of the late son of Marlina, offered a menu of chicken soup. Marlina refused and finally Marlina ordered chicken satay.

While eating, Marlina was wondering whether to take Markus' head to the police station or not. Finally, Marlina entrusted Markus' head, which had been wrapped in a wooden crate, to Topan, and headed to the police station. 
Arriving at the police station, Marlina waited for the 3 officers at the police station to finish playing ping pong. After one of the officers finished playing, Marlina finally got service.

Marlina reported that all her livestock were stolen, and that she was raped by Markus. However, this report did not receive a serious response from the authorities and questioned why Marlina would be raped if Markus was an old and thin person. The authorities also said that they needed to process the crime scene to investigate Marlina's case, while for the rape case they needed to do a post mortem and post mortem could not be done at the local police. In other words, the police cannot follow up on the rape case.

In the last chapter of the film, entitled The Birth, it is told that the driver of the transport truck that Marlina was riding before was killed by Franz and Niko. While waiting for Niko, who was burying the driver who died with a cut on her neck in the middle of the savanna, Novi's phone suddenly rang from her husband, Umbu. While talking to Umbu while sobbing, Franz seized Novi's device and Franz claimed to be Novi's good friend. Annoyed, Yohana Ian and Novi's nephews beat Franz to the ground and then rushed away in a truck leaving Franz, screaming for Niko. Niko, annoyed by Franz's stupidity, gives Franz an extra punch and then leaves.

\section{A. Results Analysis}

> Scene 1: Landscape Describe Marlina's Normal Conditions

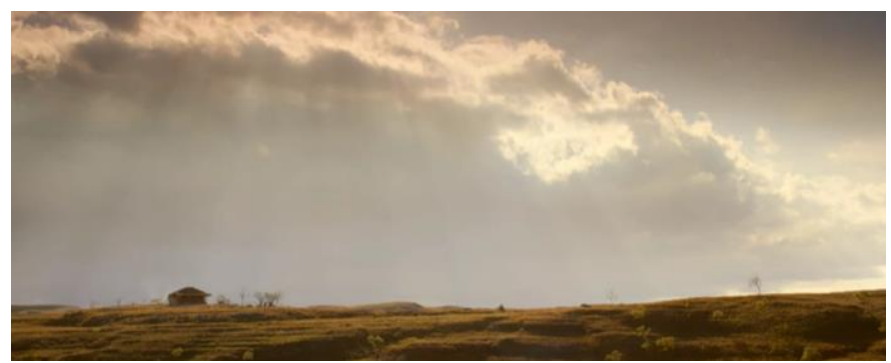

Fig 2:- Landscape Describe Marlina's Normal Conditions

The landscape shown at the beginning of the film showed the size of Marlina's small house and didn't have neighbors on either side of her house, showing that Marlina, a widow who lived alone was not a rich woman.

The next story showed Markus and Marlina was talking about Markus' plan to rob and rape Marlina with her friends because of her husband's unpaid debt. The shooting technique used in this image is eye level with a medium close up composition, showing the border of the head to the top of the chest. This technique is commonly used to confirm a person's profile (Bonafix, 845-854).

\section{Scene 2: Mark was in Front of Marlina}

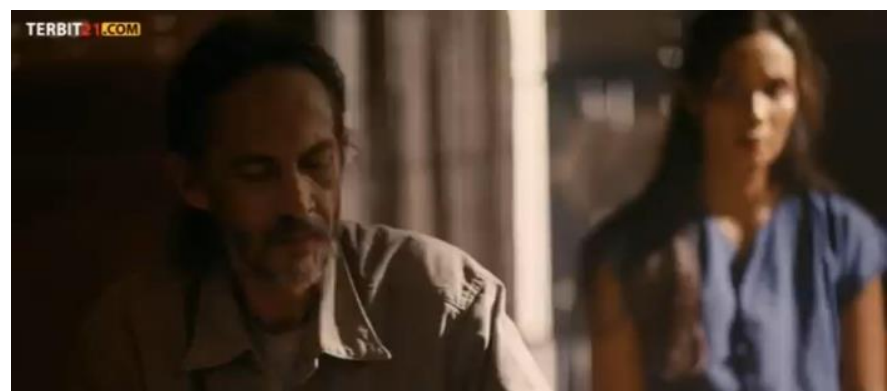

Fig 3:- Mark was in Front of Marlina

This picture showed that the position of men is in front of women, as a depiction that the nature of domination and wanting to always lead is the basic characteristic of the patriarchal system. Women tended to be behind the scenes, which in eastern culture was identified as being in the kitchen and not working, or in western culture women are still not considered equal in political activities or doing business.

In the dialogue in Figure 15, it was explicitly depicted that Markus, a man who adhered to a patriarchal system who openly said that he had more power over Marlina's body than Marlina himself. Even Markus tended to commit acts of verbal violence against Marlina by asking many things that have become Marlina's private domain, while Markus and Marlina did not have a bonded relationship. "The personal is political", which became the slogan of the radical feminism movement, came out because women's problems were often interfered with in the private realm, both covertly and in an upfront manner (Kuswidarti, 2016).

The patriarchal system itself always makes women the object of sex where sex is usually placed for the satisfaction of men, although normally in eastern cultures this only happens in the realm of marriage. The community also tends not to be exceedingly anti-violence committed by men against women, although once again this normally occurs in the realm of marriage, for certain reasons women are deemed reasonable to accept this treatment (Eriyanti, 2016).

The director tries to present 2 things that are linearly opposite. Even though in the dialogue Markus displays his dominance, he also reveals that Marlina, who should be an inferior woman, is someone "dashing", where the word "dashing" is often identified as a man - a man who is muscular, strong and has strength. If we analyzed deeper, it is in line with radical feminist ideology where women are expected not only to have a feminine side but also to have a positive masculine character, so that they support someone to become an androgynous figure in order to survive. 


\section{B. Analysis of the Actantial Model of Narrative Structure}

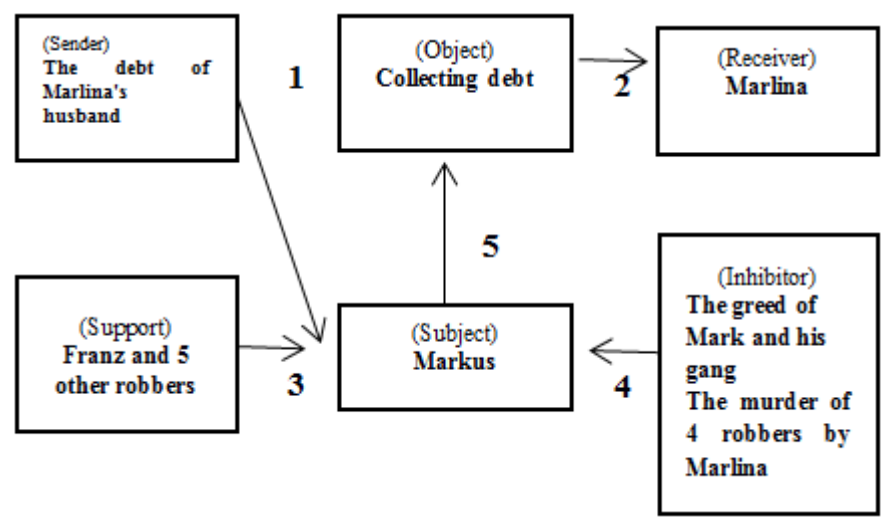

Fig 4:- MTMIFA Film's First Actantial Scheme in the Robbery Round

An arrow from the sender to the object, which in MTMIFA the position of the sender is filled with the debt of Marlina's late husband as the party that resulted in the object, namely collecting debt. The debt of Marlina's late husband arose because it was used to carry out a funeral procession for her child, named Topan.

Because the subject in the scheme of the actant is depicted as dying in the story, then in the next story the subject of the scheme of the actant will change. These changes need to be redefined in the second actor's scheme, which in the film becomes the storyline of the Second Act of Journeys and Third Act of Confession.

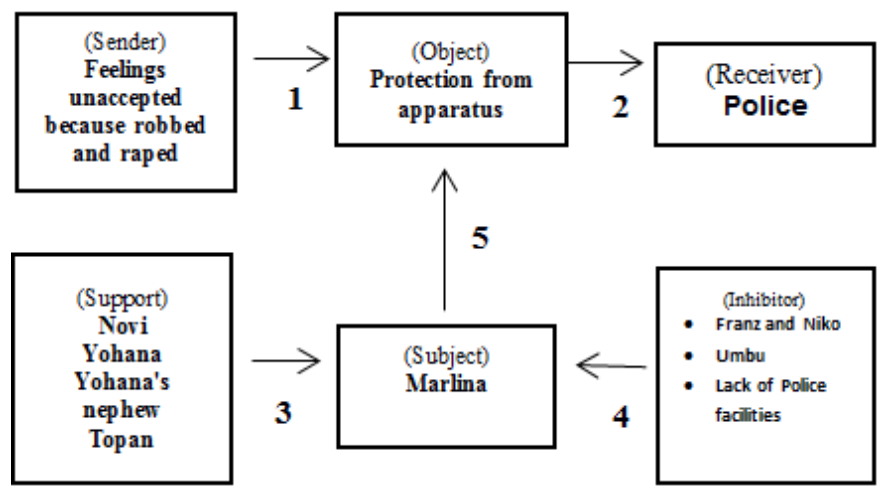

Fig 5:- MTMIFA Movie Second Actantial Scheme on Travel and Recognition Round

In this scheme, the axis of power comes a lot from the barrier (traitor) rather than from the support (adjuvant). While on the way when Marlina and Novi, who were stopping to pee, saw that their truck was stopped by Franz and one other robber friend. As a form of support for Marlina, Novi told Marlina to hide behind a bush and walk straight towards the truck that was intercepted by Franz. When asked by Franz about Marlina's whereabouts, Novi even chose to keep her whereabouts hidden.

Finally, Marlina left the police station full of grief. Marlina is comforted by the daughter of a food stall owner named Topan, who has the same name as her son. The conflict in the film then changed again after Marlina left the police station without success.
ISSN No:-2456-2165

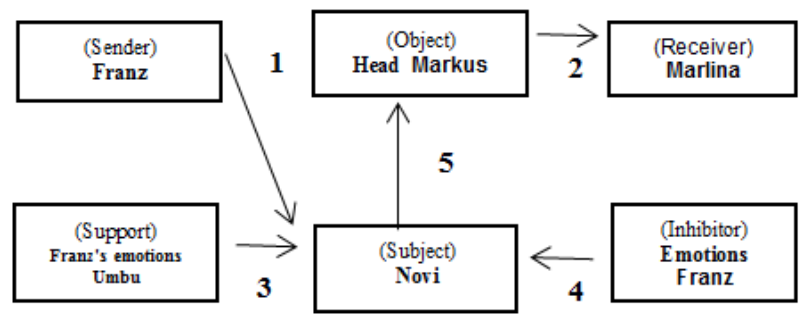

Fig 6:- MTMIFA Film's First Actantial Scheme at Birth

This third actual scheme is formed due to changing subjects. Entering the fourth or final act in this film, entitled The Birth, Novi becomes the main character in the story. Novi becomes a hostage from Franz who wants Marlina to be there, to get back Markus' decapitated head to be reunited with his body.

An interesting part of this scheme is that Franz's emotions are in both a supporting and a hindering position. Franz's emotions of anger support Franz's efforts to get Markus' head as the object he wants. By pitting Novi against her husband, Novi was finally dumped by her husband. Novi was brought to Marlina's house by Franz then asked Marlina to immediately return with Markus' head if she wanted Novi to stay safe.

\section{Functional Analysis}

In Greimas' research, functional events are arranged into a functional model in order to know how the big plot in the MTMIFA film is. Functional events are considered as main events that directly affect the development of the flow, so that other events are only considered as connecting events (Fatimah Rusmawati, 2015).

In the model shown in Table 1, it can be noted that Marlina is the main protagonist, Markus is the antagonist, with Franz being the antagonist's supporting character, and Novi is the protagonist's helper. Although Yohana and her nephew were not directly involved in the conflict, they also became supporting figures for the protagonists, while Umbu became supporting characters for the antagonists.

\section{Character and Characterization}

Greimas simplifies the characters in the narrative to heroism versus evil. In this film, the two characters are held by the four main characters in the film that help leading the story, namely Markus, Marlina, Novi and Franz. The four of them are divided to fill the role of crime (antagonist) by Franz and Mark and fill the role of hero (protagonist) by Marlina and Novi. Understanding the plot and characters in this film can also be seen using Richard Krevolin's scene-ogram chart, which scriptwriters often use to help guide the storyline and deepen the character of each character (lexwilliford.com). The scenario plot-o-gram model classifies three sub-sections in its analysis, namely the beginning of the story (prologue), the core of the story (ideological content) and the end of the story (epilogue) (Ikhsan, 2016). This model when juxtaposed with other story structure theories such as the 3 act theory popularized by Field has act 1 (beginning), act 2 (middle) and act 3 (end) (Oscario, 2011) has a similar structure in a story or MTMIFA film. 
ISSN No:-2456-2165

\begin{tabular}{|c|c|c|}
\hline \multicolumn{2}{|r|}{ Initial Situation } & $\begin{array}{l}\text { 1. Marlina, a widow who lived alone at home because her child and husband died } \\
\text { 2. Markus, a robber who went to Marlina's house to rob and intended to rape } \\
\text { Marlina, was done because Marlina's husband who had died was unable to pay his debt at } \\
\text { the funeral of his child }\end{array}$ \\
\hline \multirow{4}{*}{.气 } & Sieve Trial & $\begin{array}{l}\text { 3. Six of Markus' friends came to collect Marlina's livestock } \\
\text { 4. Markus's friend Franz teased Marlina, but ended up going to take Marlina's cattle } \\
\text { loot with one other person } \\
\text { 5. } \quad \text { Marlina was asked to cook dinner for all the robbers in her house but Marlina put } \\
\text { the poisonous saga into the chicken soup. } \\
\text { 6. } 4 \text { robbers died on the spot after eating the poisoned chicken soup } \\
\text { 7. } \\
\text { 8. Marlina was forced to have sex with Markus }\end{array}$ \\
\hline & The Ultimate Trial & $\begin{array}{l}\text { 9. Marlina took Markus' head to the police station for evidence } \\
\text { 10. Marlina meet Novi who is late pregnant on her way to the police station } \\
\text { 11. Franz found the bodies of his dead friends at Marlina's house } \\
\text { 12. Novi turned herself in to Franz while Marlina was hiding } \\
\text { 13. The police did not directly process the reports of the robbery and raped that had } \\
\text { occurred to Marlina } \\
\text { 14. Novi, Yohana, Yohana's nephew and the bus driver were taken hostage by Franz }\end{array}$ \\
\hline & Trial of Brilliance / Fall & $\begin{array}{l}\text { 15. Novi was pitted against her husband by Franz } \\
\text { 16. Novi was taken hostage by Franz then forced to call Marlina and return Markus } \\
\text { head for Novi's safety (peak of conflict) } \\
\text { 17. Novi broke her water leading to childbirth } \\
\text { 18. } \quad \text { Franz raped Marlina }\end{array}$ \\
\hline & Final Situation & $\begin{array}{l}\text { Novi saved Marlina by beheading Franz from behind } \\
\text { Novi gave birth at Marlina's house }\end{array}$ \\
\hline
\end{tabular}

Table 1:- MSPDEB Table in Greimas Functional Scheme

Then to see the inner structure in the film we can answer Richard Krevolin's seven big questions, as follows: $>$ Who is the Main Character?

The main character in this film is Marlina, it can be seen from the initial scene that Marlina is briefly introduced with the picture that she is a widow who lives alone with a small house in an area in Sumba.

\section{What does the main character want?}

Marlina wanted to get protection and justice for the robbery and rape she had from Markus.

Who / what does prevent the main character from getting what he / she want?

Marlina had obstacles not only from other actors such as Markus and Franz but also from the local patriarchal culture that oppresses women as well as the weak and imperfect local legal system.

How do you end up with the main character getting what he wanted in an extraordinary, interesting or unique way?

Marlina obtained self-protection in her own way without relying on other people by killing the robbers through chicken soup and beheading the robbers while she was being raped.

\section{What do you want to say by ending a story like this?}

The director wanted to convey that even though the patriarchal culture is growing strong enough in Indonesia, resistance to oppressive actions by the patriarchates can be done in various ways so that women do not always become the losers.

$>$ How was the story told?

The story is told chronologically, with the plot chronologically chronologically.

\section{How did the main character and other supporting characters change the story?}

- Marlina

At the beginning of the film when Markus arrived, Marlina is described as a quiet and obedient figure. Along with the threats that came to her, Marlina dared to fight back by killing the robbers who came to her house. In the end, Marlina also reported the robbery and rape she experienced to the police even though Novi had said that what Marlina had done would be in vain and it would be better for Marlina to confess at church instead of reporting to the police.

\section{- Franz}

When Franz first appeared, Franz was a polite and courteous young man to his seniors, even with Marlian he spoke softly. But after finding out that all of his colleagues are dead, Franz turns into a rude, violent man and pits Novi against her husband Umbu. 
Meanwhile, based on the character analysis per scene, it can be concluded that Marlina plays the role of the main protagonist with Novi as an additional protagonist and Yohana as a supporting protagonist who helps Marlina's story in solving problems. Then Markus becomes the main antagonist with Franz playing the role of an additional antagonist that causes conflicts to occur throughout the story. The properties of each can be described in the following table:

\begin{tabular}{|c|c|}
\hline $\begin{array}{c}\text { Character } \\
\text { Name }\end{array}$ & Description \\
\hline Marlina & $\begin{array}{c}\text { A widow in debt husband who died in debt } \\
\text { for the funeral of her late son. A brave } \\
\text { woman, civilized, quiet, full of plans, loyal } \\
\text { friend }\end{array}$ \\
\hline Novi & $\begin{array}{c}\text { A mother-to-be who is pregnant, brave, } \\
\text { uncivilized but not presumptuous, talkative, } \\
\text { loyal friend }\end{array}$ \\
\hline Mark & $\begin{array}{c}\text { A thin old man who collected debt, brave, } \\
\text { sassy, not quiet but not talkative, not loyal to } \\
\text { a friend }\end{array}$ \\
\hline Franz & $\begin{array}{c}\text { A young man, a gang of robbers, timid, sassy, } \\
\text { talkative, loyal friends }\end{array}$ \\
\hline Yohana & $\begin{array}{c}\text { An old woman who was a public transport } \\
\text { passenger, brave, civilized, talkative, loyal } \\
\text { friend }\end{array}$ \\
\hline Table 2:- Characters
\end{tabular}

Table 2:- Characterization of MTMIFA Movie Characters

\section{E. Semiotic Square}

The theme of resistance to patriarchal domination is the main story raised in the MTMIFA film. The depiction of how Markus is being sassy towards Marlina verbally at the beginning of the film is an introduction that many men still often dominate women and interfere in private affairs, especially in Indonesia which adheres to the Eastern ideology where men are still considered higher in rank than women.

In the film, a female figure is depicted with a beautiful face and ideal body so that it can become an imagination for the viewing audience so that she wants to be what she sees. In this case, women's bodies are often used as exploitation. It is called exploitation because of the element of pornography that shows women as objectivity and is always a spectacle (Fadhilah, 2017).

Films about violence against women often show how women often experience acts of oppression and never fight back or get the proper defense so that stories of violence often end up traumatically and even commit suicide. However, in the MTMIFA film, several female characters who, although still adab to the East, have masculinity to show the strengths of women both explicitly and implicitly. These properties can be described in the semiotic square chart as follows.

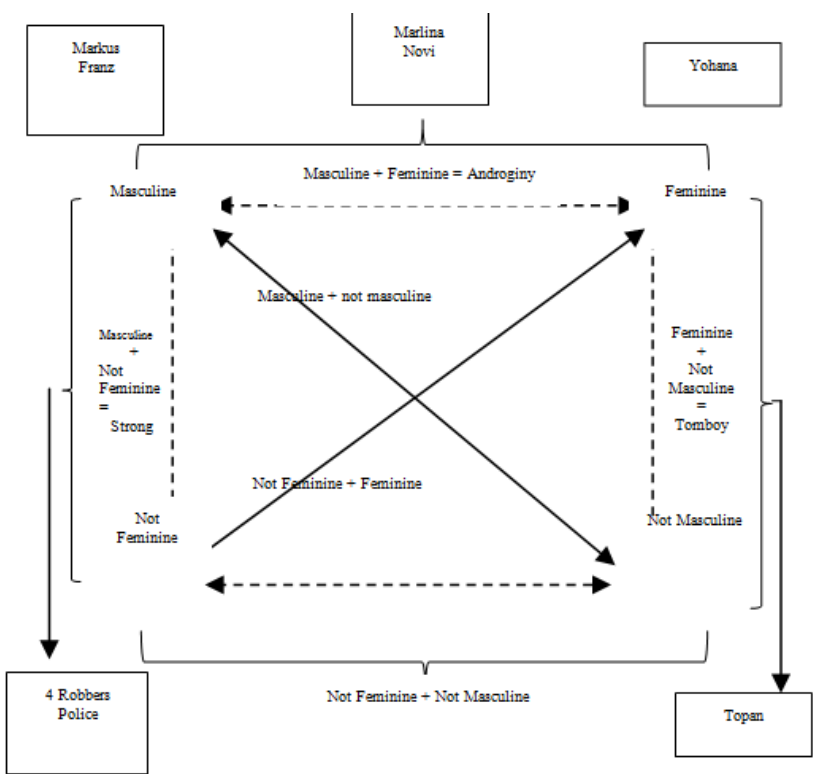

Fig 7:- Masculine vs Feminine Semiotic Square Chart

The use of masculine and feminine categories was chosen to distinguish the binary opposition believed by patriarchs where there is always a line between men and women, both in the realm of sexuality and other domains. The worst thing about the binary opposition in this patriarchal system is that it creates oppressive actions from men to women. And Marlina is an embodiment of the androgynous nature of radical feminists which allows a person to become a full self by being able to show his masculine and feminine feelings (Tong, 1998).

This film tells that male masculinity is often supported by the customs adopted by a place. The MTMIFA film was shot in Sumba, Indonesia, where the oriental patriarchal culture that upholds customs and manners is still very powerful.

The form of civilization does not only want to be displayed between men and women, but also from the young to the older ones. Like when Franz was trying to seduce Marlina to serve chicken soup first to her but was finally caught by older robbers named Raja, Raja scolded Franz with said, "Little boy wants to eat first" then told him to immediately go and bring all Marlina's cattle to sell.

Yohana's civilized + not presumptuous side. He was very polite to Marlina, even though he was much older. Seen when they were in the truck on the way to the police station. Yohana calmed Marlina who was sitting at the front while pointing a machete at the driver. Finally Marlina moved to the passenger seat with Markus' head starting to rot and smell, however, Yohana apologized to Marlina for not sitting next to him by saying, "I don't want to sit beside you", while covering her nose because of the bad smell and finally Yohana spat because she felt nauseous. This makes Yohana to be in a civilized + not presumptuous place which is here stated as ethical. 


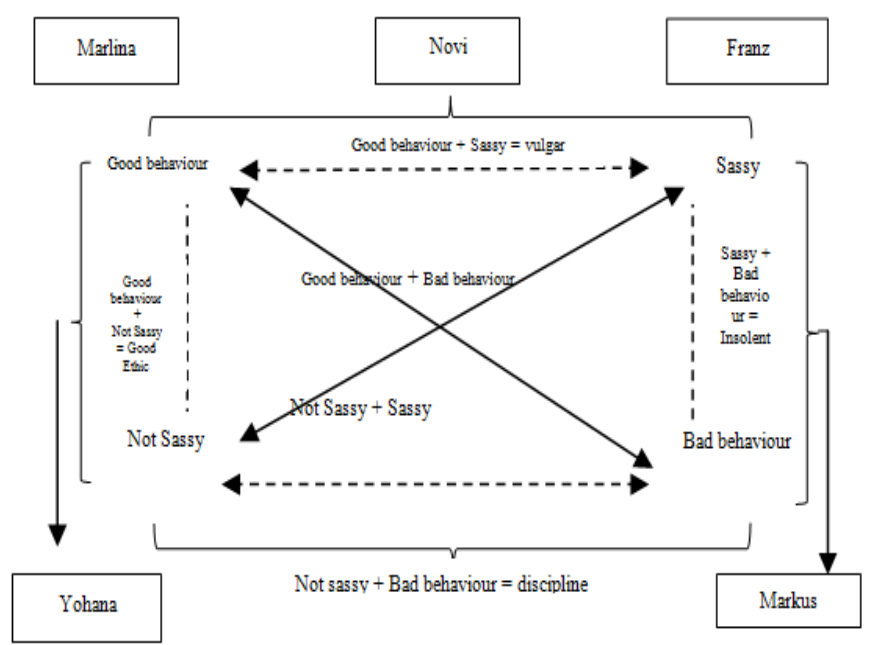

Fig 8:- Semiotic Square Civilized VS Sassy

\section{DISCUSSION}

Patriarchy is the main issue raised in the film Marlina the Murderer in Four Acts. An issue that is still ingrained in eastern culture, especially in Indonesia. Not only does it interfere with the role of women in the domestic sphere but also the absence of equality in the economic, political and legal realms.

In fact, if pulled back, Indonesia has RA Kartini and Cut Nyak Dien who were known as female voice fighters in their era. Or in the current era, the name Gadis Arivia is the founding activist of the Women's Foundation who continues to study feminism in theory and cook up interesting discussions in Indonesia from publishing journals. There is also Ratna Sarumpaet who is often viral because she always promotes pro-democracy, especially for women, even though in a less eastern way. This shows that feminism in Indonesia is never gone.

However, Indonesia is a country with Muslim as the majority. Where patriarchy is often identified in accordance with Islamic teachings, male nature takes precedence. Even in 2019, the \#uninstallfeminism and \#Indonesiatanpafeminis movements emerged which echoed that to respect women's rights, it is not necessary to follow feminism but simply to be Islamic in kaffah. Even a wellknown Ustaz in Indonesia Felix Siauw also said that the incarnation of men and women is an insult to nature because women are forced to follow male nature (Primastika, 2019). In fact, if studied again in their knowledge, feminism talks about men and women as gender, not as gender. However, Islam does not recognize gender in its book.

Feminism exists to make women have control over themselves. Feminism exists because it sees many involvement of men and the injustice that befalls women which not only make women invisible due to discrimination but also become victims because of a lot of exploitation.
Films are often used as a medium for expressing ideas, one of which is the idea of fighting against patriarchal domination, which is still common in Indonesia. Although film is often regarded as a popular medium that only serves as entertainment, it is often the case that films succeed in constructing an ideology. But as a narrative research, as the aim of the analysis is to meet the needs of listeners who need storytellers. The term narrative emerges with a focus on the study of actors, stories at the beginning of the middle and at the end, relationships and functions and motives (Sobur, Narrative Communication, 2016). So that from here the storyteller can start analyzing various aspects of people's life from culture, religion, politics and so on.

The use of western style is an idea chosen so that this film can be widely accepted. Given that everyone will be more popular with the western genre, which in general is also in accordance with the background of Sumba's life, always telling stories about life in the middle of a large area with a very sparse population, mid to low economic life, high levels of violence but with minimal role of law enforcement officers. An international film reviewer from Variety.com even called the MTMIFA film the first Satay Western genre film (Lee, 2017).

The concept of western feminist is an appropriate term taken from the MTMIFA film (Rahad, 2017). Where the western genre is often known for its masculinity, the figure of a strong man with weapons, acting heroically in various acts of violence and riding a horse is converted into a feminist form, which has the same character but is packaged in the female gender.

Feminism in the film Marlina is not like the feminismmovement in general which demands gender equality. Marlina's difficulty in living alone in an area like Sumba has become a struggle that being a woman turns out to be an independent figure who doesn't rely on other people, especially men. Marlina is present as a fantasy figure to fight against the patriarchal domination that still occurs in Indonesia, which results in women being the victims of all forms of violence and harassment. Not only does it represent women in Sumba, but almost women in all ethnic groups in Indonesia.

Judging by the problem, the impact of patriarchal culture in Indonesia enters the system of the blame approach, namely problems caused by a system that is not running according to your wishes or expectations (Siti, 2017). Various problems that arise such as domestic violence and sexual harassment which are supported by a weak legal system make victims often do not have the courage to fight back. The absence of protection for victims has resulted in victims often experiencing repeated violence. In addition, it is difficult to report this crime because various supporting evidence is needed, such as witnesses and post mortem results, which in turn are increasingly incriminating the victim. 
The incompetence of law enforcement officers in this film also takes the concept from western films where in a remote area with a small population, oftenly only a number of officers or known as a sheriff who can be counted on the fingers. With an almost non-existent sense of responsibility, protection for crime victims is almost impossible to obtain at a police station, which requires quite a long distance to reach it. Whereas the sheriff in the western often ignores civilians by drinking coffee, smoking and a donut, while in this film the officers are depicted busy playing ping pong.

In contrast to women who often do not have control over their lives, men in a patriarchal system often dominate in every decision making, especially in the household sphere. Radical - cultural feminism strongly opposes the habit of men to make women their sexual objectivity, especially for those who commit acts of sexual violence against women.

Patriarchy often makes women the objectivity of their sexual needs. Calling the female body as an object, such as mentioning sexy or curvaceous, is often done by men, and although it is considered as harassment, this is often seen as just a fad. However, if the same thing happens in reverse, it often gets an exaggerated response to the point that women are considered "itchy" or not a good woman.

Like when it went viral on social media, many women commented when Jonathan Cristie, who won a gold medal at the 2019 Asian Games, took off his clothes showing his athletic body. Comments about Jonathan's actions that make the "hot womb" become a conversation on many social media to several articles. The debate whether this is a form of admiration or harassment is a topic of discussion.

This happens because in Indonesia the understanding between genders is still quite rigid, and discussion regarding matters relating to sex and reproductive organs is taboo to discuss. The arguments issued are still limited to that - that is, "If you don't want to be harassed, Jojo should not take off your clothes", as well as, "If you don't want to be raped, don't wear a mini skirt". In terms of the Criminal Code itself, verbal sexual harassment is still difficult to follow up considering that what is categorized as sexual violence only involves bodily contact (Perempuan, 2019, p.53).

This film gives a discourse to the audience, that although in fact the choice is often the most difficult thing to find in a patriarchal system, between fighting or accepting oppression, it is not impossible to fight against exploitation that is detrimental to women. This one-and-ahalf hour film wants to invite women to be able to make choices that can be made to fight against harmful acts of male domination, even though resistance by means of this film cannot be legally justified.

Even though the journey in demanding equality is still quite long, at least the depiction of patriarchal stories in the film Marlina can be an evaluation method for all groups, from men as heads of families, law enforcement officials and legislative institutions that there are still many deficiencies in efforts to protect girls. And if women are seen as inferior, it would be better if the perceptions for discrimination, oppression and exploitation are slowly transformed into an effort to protect.

\section{A. Analysis Summary}

Two issues that often attract public attention are violence and sex. The MTMIFA film brings these two issues to the screen, and packs them together in the form of resistance to patriarchal domination, where patriarchal culture, especially in Indonesia, often leads to violence, especially sexual violence. Female inferiority and forms of patriarchal domination are immediately felt in the early stages of the film, which are directly played by the two main characters Marlina and Markus.

Furthermore, analysis of the narrative structure is carried out to define the actors who play a role in carrying out the plot of the film. The purpose of this analysis is to find out what makes the narrative work, which Algirdar Greimas calls this role as an actor. It is called anything because the roles can be filled by actors or other strengths / goals. From the analysis conducted by the author, there are 3 schemes of actors with different subjects obtained during the course of the film.

In the first actantial scheme, Markus became the leader of a plot where he wanted to pay Marlina's late husband's debt by taking all of Marlina's livestock and raping Marlina. To support this action, Franz and 5 other robbers were in support acting. However, this action did not go smoothly because Marlina killed 4 of her robber friends using chicken soup, and because of her greediness that did not leave immediately after getting Marlina's cattle, Markus died while raping Marlina with his own machete.

In the second actantial scheme, Marlina took over the subject's position with the object of reporting to the police regarding the robbery and rape she had experienced. During this trip Marlina encountered a lot of obstacles, where she had to hide while traveling because she was being chased by Franz and one other robber because she had killed Mark and took his head away. When she arrived at the Marlina police, she had to face disappointment because of the difficult procedures for reporting robbery and rape she experienced, so that the report could not be processed immediately and there was no protection that would be obtained by Marlina until the investigation process was completed.

In the third actantial scheme, this is quite interesting because Franz's emotions occupy 2 positions at once, as a support and an obstacle to him in getting Markus' head. Becoming a supporter when an emotional Franz dares to slander Novi in front of Umbu and even acts harshly on Novi, making Novi's guts dim. It became an obstacle because when returning to Marlina's house, she was too late in sadness and anger because Markus, his friend and leader had to die with his head cut off so that it made him off guard and it was easy to finally be injured by Novi to death, even though Novi was experiencing severe contractions because he was about to give birth, while raping Marlina. 
After that the active scheme is made, the functional scheme becomes the next analysis to find out how the stages of events that occur are in accordance with the stages of the functional scheme according to Greimas. These stages are divided into the initial situation, the sieve test, the main trial, the glory / fall trial and the final situation that becomes the end of the story. In the MTMIFA film, the author categorizes 19 events that are important in the film.

From the schemes of the actor, the author also found that there are several characters that stand out in this film to be used as a guide in carrying out Greimas' semiotic square analysis, namely Markus, Marlina, Franz and Novi. The four of them are main characters who have opposing characters, such as masculine-feminine, sassy, polite-rude.

The characteristics above are the values taken in the binary opposition, Masculine versus Feminine and Civilized versus Presumptuous, added with the subcategories of Non-Masculine versus Non-Feminine and Uncivilized versus Non-lancing. Each character occupies their respective categories according to their characters in the film. Although it tells about patriarchal domination by men, Marlina as the main character in this film is in the category of feminine + masculine or given the androgynous meta-term. The androgynous meta-term was given because Marlina was able to present her feminine figure in various behaviors such as cooking, dressing up, speaking politely but also displaying her masculinity by fighting against the plan to rape the robbers by murdering her through the chicken soup she cooked and slashing Mark's neck with a machete.

A patriarchal-themed film, but made by a female director, seems to want to break the concept of Male Gaze, which is often found in women's-themed films, where women are often used as objectification of men. Described as a figure of a beautiful woman, sexy but powerless so that it can be oppressed in such a way. The concept of Male Gaze, which was introduced by Laura Mulvey, describes the objectification of women in the form of women's inability to become subjects and the identification of narcissistic audiences, which then has implications for a sense of victory over power. The forms of oppression that are shown in the MTMIFA film, but only exist in the initial situation to lead the story to the main screening and trial trials in the Greimas functional analysis.

Marlina shows that patriarchy does not always win, even though patriarchy in Indonesia still dominates because of the support of the growing patriarchal culture in Indonesia, the majority of the population is Muslim who have a higher understanding of male nature and also the legal protection system of the country that is weak. Marlina pointed out that resistance does not always require support from many parties but can be done from yourself because this form of oppression can be accepted by women at any time.

\section{CONCLUSIONS AND SUGGESTIONS}

The dominance of patriarchy is the main issue in this film. This conflict can be seen throughout the plot, forms of patriarchal domination appearing in several forms, such as verbal abuse, violence to rape. Marlina as the main character in the MTMIFA film is a form of androgin figure, like how radical feminists expect humans to have positive figures of femininity and masculinity at the same time, so that they are able to survive and work together in their social life. This is also reflected in the character Novi who is the supporting actor for Marlina, and Franz as the antagonist. This film looks so balanced, from showing the masculine and feminine side to the combination of the two of each character.

From the analysis of the Greimas narrative carried out on the MTMIFA film, it is found that the main conflict that governs the plot and its development is about masculine vs feminine. The depiction of forms of oppression at the beginning against women is only a description of the initial situation that will lead the story to transformation and then the subject in this film is controlled by female characters. The meaning of the text in the MTMIFA film is categorized through the Greimas semiotic quadrilateral which consists of masculine, feminine, not masculine and not feminine. The masculine camp is played by antagonist characters in the film, where the majority of them commit oppression against women such as Markus, Franz, 4 Robbers and the Police. Meanwhile, Marlina and Novi occupy the masculine + feminine category which is given the androgynous metaterm.

Although this film teaches against the domination of patriarchy, some forms of resistance in this film teach that every action always has a consequence.

\section{RESEARCH LIMITATIONS}

This study only discusses the social value of films with the Greimas narrative semiotics model there are still several other methods to explore social reality in a film, such as using Charles Sanders Pierce's grand theory, Sara Mills' feminist semiotics or John Fiske's television code ideology level. The results may differ if the film is peeled off with other semiotic models.

\section{REFERENCES}

[1]. Adji, T. S. (2016). Penulisan Skenario Bergenre Fiksi Ilimiah Mengangkat Keunikan Kartografi Kota Dengan Pendekatan Riset Sejarah "Atmodirono". Jurnal ISI Vol 8 No 2 Desember 2016, 184-191.

[2]. Andi Tenri Pada Agustang, M. S. (2015). Perkembangan Peran Jender Dalam Perspektif Teori Androgini. ojs.unm.ac.id, 116-123.

[3]. Ardianto, E. \&. (2004). Komunikasi Massa suatu Pengantar. Bandung: PT Remaja Rosdakarya.

[4]. Arsi, M. (July de 2019). Makna Identitas Budaya dan Konflik Antaretnis dalam Film "Crazy Rich Asians". MediaTor Vol 12, 46-60. Obtenido de elibrary.lspr.edu: http://elibrary.lspr.edu/ 
[5]. Bahasa, T. P. (1990). Kamus Besar Bahasa Indonesia. Jakarta: Balai Pustaka.

[6]. Basarah, F. F. (2016). Feminisme Eksistensialis Tokoh Katniss Everdeen Dalam Serial Film The Hunger Games (Analisis Semiotika Roland Barthes). journal.ubm.ac.id.

[7]. Bonafix, D. N. (845-854). Videografi : Kamera dan Teknik Pengambilan Gambar. journal.binus.ac.id, 2011.

[8]. Brzeski, P. (12 de December de 2018). Hollywoodreporter.com. Obtenido de Hollywoodreporter.com: https:/www.hollywoodreporter.com/news/feministwestern-marlina-murderer-sweeps-indonesian-filmawards-1168559

[9]. Dargis, M. (21 de June de 2018). The New York Times. Obtenido de The New York Times: https:/www.nytimes.com/2018/06/21/movies/reviewmarlina-the-murderer-in-four-acts.html

[10]. Darwin, M. (1999). Maskulinitas : Posisi Laki-laki Dalam Masyarakat Patriarkis. Gadjahmada University S.281.

[11]. Effendi, O. U. (2003). Ilmu, Teori, dan Filsafat Komunikasi. Bandung: PT Citra Aditya Bakti.

[12]. Elfira, K. S. (2014). Pengaruh Budaya Patriarki Terhadap Kekerasan Dalam Rumah Tangga Terhadap Perempuan Pada Masa Federasi Rusia : Sebuah Tinjauan Feminisme Marxis. lib.ui.ac.id.

[13]. Eriyanti, L. D. (2016). Pemikiran Politik Perempuan Nahdlatul Ulama (NU) dalam Perspektif Feminisme : Penelusuran Pemikiran Mainstream dan NonMainstream. Jurnal Ilmu Sosial dan Ilmu Politik Vol 20 No 1, 68-93.

[14]. Eriyanto. (2013). Analisis Naratif. Jakarta: Kencana Prenada Media Group.

[15]. et.al, J. A. (1993). Feminist Philosphies : Problem Theories and Aplication. New Jersey: Prentice Hall.

[16]. Fadhilah, U. (2017). Narasi Eksploitasi Perempuan Dalam Film Perempuan - Perempuan Liar. eprint.ums.ac.id.

[17]. Fatimah Rusmawati, R. H. (2015). Kasih Sayang Ayah Dalam Film Analisa Naratif Film Mirracle in Cell No 7 Dengan Teori Algirdas Greimas. e-proceeding of Management : Vol 2, 4318.

[18]. Faturochman. (2001). Keadilan Perspektif Psikologi. Yogyakarta: Pustaka dan Fakultas Psikologi UGM.

[19]. Ghozali, D. M. (2005). Comunication Measurement; Konsep Dan Aplikasi Pengukuran Kinerja Public Relation. Bandung: Simbiosa Ekatama Media,.

[20]. Griffin, E. (2011). A First Look At Communication Theory. New York: McGraw-Hill.

[21]. Hébert, L. (2011). Tools for Text and Image Analysis An Introduction to Applied Semiotics. Quebec: Université du Québec à Rimouski.

[22]. Hidayat. (2002). Metodologi Penelitian dalam Sebuah "Multi-Paradigm Science". ejournal.unisba.ac.id.

[23]. Ikhsan, F. (2016). The Meaning of Investiagate Journalism (Analysis of Semiotics Using Model Roland Barthes). elib.unikom.ac.id.

[24]. Imran, H. A. (2015). Semiotika Sosial dan Analisis Teks dalam Penelitian Komunikasi Pendekatan Kualitatif Berbasis Teks. academia.edu.
[25]. Istiqomah, N. (2017). Aplikasi Semiotika Naratif A.J. Greimas Terhadap Kisah Thalut Dalam Al Quran. QOF Vol 1 No 2, 79-88.

[26]. Jawa Pos. (26 de September de 2017). jpnn.com. Obtenido de jpnn.com: https://www.jpnn.com/news/film-indonesia-inidisebut-melahirkan-genre-satay-westren

[27]. Jones, S. J. (2010). Teori-Teori Feminis Kontemporer. Yogyakarta: Jalasutra.

[28]. Kamil, A. (28 de Mei de 2017). Kompas.com. Obtenido de Kompas: https://entertainment.kompas.com/read/2017/05/28/15 0000310/kekuatan.perempuan.bernama.marlina.dalam .budaya.patriarki?page=all

[29]. Kania, D. D. (15 de Mei de 2012). thisisgender. Obtenido de thisisgender: https://thisisgender.com/isugender-sejarah-dan-perkembangannya/

[30]. Keda, P. O. (12 de Juli de 2017). Detik.com. Obtenido de Detik.com: https://news.detik.com/berita/d3557430/kunjungan-ke-sumba-jokowi-dihadiahikuda-dan-parang

[31]. Kemdikbud. (2016). kbbi daring. Obtenido de kbbi.kemdikbud.go.id: https://kbbi.kemdikbud.go.id/entri/tahanan

[32]. Kholil, M. (2016). Feminisme dan Tinjauan Kritis Terhadap Konsep Gender Dalam Study Islam. FAUIM, 1.

[33]. Knight, C. (29 de Juni de 2018). National Post. Obtenido de Nationalpost.com: https://nationalpost.com/entertainment/movies/marlin a-the-murderer-in-four-acts-is-a-darkly-funny-dramaand-a-true-triumph

[34]. Kourany, J. A. (1993). Femininist Philosophies: Problem Theories and Aplication. New Jersey: Prentice Hall. Inc.

[35]. Kristanto, J. (2007). Katalog Film Indonesia 19262007. Jakarta: Penerbit Nalar.

[36]. Kuswidarti, Y. (2016). Politik Seksual Dalam Novel Lemah Tanjung, Pecinan Kota Malang, Dan 1998 Karya Ratna Indraswari Ibrahim. e-journal.unair.ac.id.

[37]. Lee, M. (26 de May de 2017). Variety. Obtenido de Variety:

https://variety.com/2017/film/reviews/marlina-themurder-in-four-acts-review-1202446324/

[38]. lexwilliford.com. (s.f.). lexwilliford.com. Obtenido de lexwilliford.com: http://www.lexwilliford.com/Workshops/Screenwritin g/Assignments/The_Ackerman_Scenogram.pdf

[39]. Lie, S. (2005). Pembebasan Tubuh Perempuan. Jakarta: Grasindo.

[40]. Lincoln, N. K. (1994). Handbook of Qualitative Research. United Kingdom: SAGE .

[41]. Lolita, L. (12 de Decemebr de 2019). Brilio.net. Obtenido de Brilionet: https://www.brilio.net/film/marlina-9-film-ini-raihpiala-citra-tapi-kurang-laku-di-pasaran-181212v.html\#

[42]. Maryaeni. (2005). Metode Penelitian Kebudayaan. Jakarta: Bumi Aksara.

[43]. Miyarso, E. (2009). Developing of Interactive Multimedia for the Study of Cinematography. State Universuty of Yogyakarta, 1. 
[44]. Moleong, L. (2002). Metodologi Penelitian Kualitatif. Bandung: PT Remaja Rosdakarya.

[45]. Moleong, L. J. (2004). Metodologi Penelitian Pendidikan Kualitatif. Bandung: PT Remaja Rosdakarya.

[46]. Mudjiono, Y. (2011). Kajian Semiotika Dalam Film. Jurnal Ilmu Komunikasi, Vol. 1, No.1.

[47]. Mukarom, Z. (2008). Perempuan dan Politik: Studi Komunikasi Politik tentang Keterwakilan Perempuan di Legislatif. MediaTOR Vol 9 No 2 Desember 2008, 257-270.

[48]. Mulyana, D. (2002). Metodologi Penelitian Kualitatif. Bandung: PT Remaja Rosdakarya.

[49]. Muslim. (2015). Varian-Varian Paradigma, Pendekatan, Metode, dan Jenis Penelitian Dalam Ilmu Komunikasi. Wahana Vol 1 No 10 Ganjil, 77-85.

[50]. Norman K. Denzin, Y. S. (1994). Handbook of Qualitative Research. United Kingdom: Sage Publication.

[51]. Nur, B. M. (2013). Semiotika Dalam Metode Penelitian Komunikasi . Jurnal Penelitian Komunikasi, Informatika dan Media Massa PEKOMMAS Vol 16, 73-81.

[52]. Nurgiyantoro, B. (2002). Teori Pengkajian Fiksi . Yogyakarta: Gadjah Mada University Press.

[53]. Oscario, A. (2011). Penerapan Teori Struktur Cerita Pada Pembuatan Film. Humaniora Vol 2, 1247-1259.

[54]. Pangerang, A. M. (19 de September de 2018). Marlina si Pembunuh dalam Empat Babak Wakili Indonesia di Seleksi Oscar 2019. Jakarta, Indonesia.

[55]. Perempuan, K. (27 de September de 2019). Komnasperempuan.go.id. Obtenido de Komnasperempuan.go.id: https://www.komnasperempuan.go.id/file/Laporan $\% 2$ 0Independen $\% 20$ Komnas $\% 20$ Perempuan $\% 20 \mathrm{BPfA}+2$ $5 \% 20(1) \cdot p d f$

[56]. Primastika, W. (8 de April de 2019). Tirto.id. Obtenido de Tirto.id: https://tirto.id/uninstallfeminism-benarkah-indonesiatak-butuh-feminisme-dlfE

[57]. Purwanti, T. (17 de November de 2017). Magdalene. Obtenido de Magdalene.com: https://magdalene.co/story/marlina-pembunuh-yangmelawan-patriarki

[58]. Rahad, R. (18 de November de 2017). Vice. Obtenido de $\quad$ Vice: https://www.vice.com/id_id/article/kz39xy/perempuan -sumba-adalah-karakter-terbaik-untuk-film-western

[59]. Rahardjo, M. (2018). Paradigma Interpretif. Obtenido de repository.uin-malang.ac.id: http://repository.uinmalang.ac.id/2437/1/2437.pdf

[60]. Rahayu, E. M. (1 de April de 2018). Kumparan. Obtenido de Kumparan: https://kumparan.com/swaonline/angin-segar-industrifilm-nasional

[61]. Retnowulandari, W. (2010). Budaya Hukum Patriarki Versus Feminis : Dalam Penegakan Hukum Dipersidangkan Kasus Kekerasan Terhadap Perempuan. portal.kopertis3.or.id, 16-57.

[62]. Ringham, B. M. (2000). Dictionary of Semiotics. London \& New York: Cassel.
[63]. Robiansyah, A. (2015). Konstruksi Realitas Kaum Perempuan Dalam Film "Wanita Tetap Wanita" (Analisis Semiotika Film"Wanita Tetap Wanita"). ejournal.ilkom.fisip-unmul.ac.id, 504-518.

[64]. Sartini, N. W. (2017). Tinjauan Teoritik tentang Semiotik. journal.unair.ac.id.

[65]. Siti, A. I. (2017). Menyoroti Budaya Patriarki di Indonesia. Social Work Journal.

[66]. Sobur, A. (2006). Semiotika Komunikasi. Bandung: PT Remaja Rosdakarya.

[67]. Sobur, A. (2016). Komunikasi Naratif. Bandung: Rosdakarya.

[68]. Sofranita, B. D. (2015). Pemikiran dan Tindakan Tokoh Helen Dalam Feuchtgebiete Karya Charlotte Roche (Perspektif Feminisme Radikal-Libertarian). Identitaet-VOL IV No 2-Juni 2015.

[69]. Sudrajat, F. R. (2015). Kasih sayang Ayah Dalam Film Analisa Naratif Film Miracle in Cell No 7 Dengan Teori Alagirdas Greimas. e-Proceeding of Management : Vol.2, 4318.

[70]. Syah, A. Z. (2017). repository.uinjkt.ac.id. Obtenido de repository.uinjkt.ac.id: http://repository.uinjkt.ac.id/

[71]. Thomson, D. (2001). Radical Feminism Today. Sage Publication, 135.

[72]. Tong, R. P. (1998). Feminist Thought. Yogyakarta: Jalasutra.

[73]. Vebrynda, R. (2014). Korupsi dalam Film Indonesia. Jurnal Ilmu Komunikasi Vol 11 No 2, 151-164.

[74]. Whelehan, J. P. (s.f.). Fifty Key Concepts in Gender Studies. London: Sage Publication.

[75]. Wibowo, I. S. (2009). Semiotika Aplikasi Praktis Bagi Penelitian Dan Penulisan Skripsi Mahasiswa Ilmu Komunikasi. Tangerang: Fakultas Ilmu Komunikasi Universitas Prof Dr Moestopo (Beragama).

[76]. Wisnubrata. (10 de November de 2018). Kompas.com. Obtenido de Kompas.com: https://ifestyle.kompas.com/read/2018/11/10/2044085 20/kenapa-korban-pemerkosaan-tak-bisa-berkutikmelawan?page $=$ all

[77]. Yumnasa, F. (2018). Gambaran Perempuan Dalam Dominasi Kekuasaan Laki-laki Pada Novel Psycopat Diary. repository.unair.ac.id.

[78]. Yunus, S. d. (2008). Ketrampilan Dasar Menulis. Jakarta: Universitas Terbuka 